\title{
The Essential Oils and the Effect on Infection-Causing Pathogenic Viruses
}

\author{
Flores-Encarnación, M. ${ }^{1}{ }^{*}$, Valentín-Aguilar I. ${ }^{1}$, Aguilar-Gutiérrez G.R. ${ }^{2}$, García-García S.C. ${ }^{3}$, \\ Carreño-López R. ${ }^{3}$, Xicohtencatl-Cortes J. ${ }^{4}$, Cabrera-Maldonado C. ${ }^{5}$ \\ ${ }^{1}$ Laboratorio de Microbiología Molecular y Celular. Biomedicina, Facultad de Medicina, Benemérita \\ Universidad Autónoma de Puebla. Puebla. Puebla, México \\ ${ }^{2}$ Centro de Investigación sobre Enfermedades Infecciosas. Instituto Nacional de Salud Pública. Cuernavaca, \\ Morelos. México \\ ${ }^{3}$ Centro de Investigaciones Microbiológicas. ICUAP. Benemérita Universidad Autónoma de Puebla. Puebla. \\ Puebla, México \\ ${ }^{4}$ Hospital Infantil de México Federico Gómez. Ciudad de México. México \\ ${ }^{5}$ Facultad de Ciencias Químicas, Benemérita Universidad Autónoma de Puebla. Puebla. Puebla, México \\ *Corresponding Author: Flores-Encarnación M., Laboratorio 421 Edif. EMA1. Biomedicina. Facultad \\ de Medicina. Benemérita Universidad Autónoma de Puebla. 13 sur 2702, Col. Volcanes, C.P. 72410. \\ Puebla, Puebla, México.
}

\begin{abstract}
It has been necessary to search for new substances to combat infectious diseases caused by bacteria, especially bacteria that are multi-resistant to antibiotics. The same happens to be able to fight some viral diseases, especially emerging infections. As result of the above, the use of various substances of plant origin have been proposed. In this context, essential oils of plants, composed of aldehydes, alcohols, terpenoids and other compounds, have found wide application as alternatives to conventional therapy and food preservation, as also the treatment of various viral diseases.
\end{abstract}

Keywords: Essential oil, pathogen, virus, antiviral, antibacterial.

\section{INTRODUCTION}

The antibiotic resistance that bacteria have shown has been one of the great public health problems that have been registered in the world. Microorganisms seem to adapt quickly to their environment, especially to stressful environmental conditions and the presence of antibiotics or disinfectants used by man (Marton et al., 2016). For this reason, it has been necessary to search for new substances to combat infectious diseases caused by bacteria, especially bacteria that are multi-resistant to antibiotics. As result of the above, the use of various substances of plant origin have been proposed (Flores-Encarnación et al., 2016). Different research groups in the world have reported the use of plant extracts or their derivatives, which have antibacterial properties. As antibacterial agents, the essential oils act against a wide range of pathogenic bacteria including Bacillus cereus, Listeria monocytogenes, Staphylococcus aureus, Salmonella typhimurium, Shigella dysenteriae, E. coli O157:H7, uropathogenic E.coli (Al-Shuneigat et al., 2014; Flores-Encarnación et al., 2018; Hussein et al., 2014; Sambyal et al., 2017; Shuaib et al., 2016; Upadhyay et al., 2013). In the last decades, numerous infectious diseases have emerged and re-emerged affecting to humanity. As microbial causative agents have been the so-called 'exotic agents', which have been impacted to public health systems due to limited experience in case management and lack of appropriate resources (Ahmed et al., 2017). In most cases, these 'exotic agents' are zoonotic agents transmitted directly from animals to man or via vectors (Feldmann et al., 2002). As they are new infectious diseases for humans, they often lack the necessary experience to combat these infections, both in the use of antimicrobials (for example, antivirals) and in the existence of vaccines (Ahmed et al., 2017). Therefore, this work shows the most relevant aspects ofsome essential oils and the effect of them on infection-causing viruses of medical importance. 


\section{THE ESSENTIAL OILS}

Plants can produce different types of metabolites which have been exploited by humans with beneficial roles. So, many of the secondary metabolites that are produced in plants have been used as pesticides over time (Adeyemi, 2010). As is known, primary metabolites include amino acids, simple sugars, nucleic acids and lipids are compounds necessary for cellular processes, while secondary metabolites include compounds produced in response to stress, such as the case when acting as a repellent to herbivorous organisms or in response to external stimuli such as nutritional changes (Adeyemi, 2010; Hamid et al., 2011). In addition to use as a pesticide, plant extracts or their metabolites have been used for centuries to treat infectious diseases and they are considered as an important source of new antimicrobial agents (Bereksi et al., 2018; Cowan, 1999). Several works have been done to examine the antimicrobial effects of herbal plants extracts, including roots, stem, leaves or flowers (Abbassi and Hani, 2012; Abu-Shanab et al., 2005; Cowan, 1999). Currently, the antimicrobial properties of plant extracts and essential oils and the research of alternatives for treatment of infectious diseases are being studied.

Essential oils of plants are composed of a mixture of aldehydes, alcohols, terpenoids and other compounds (Diao et al., 2013). Currently the plant products have found wide application as alternatives to conventional therapy and food preservation, as also the treatment of various diseases by theirs antioxidant and anti-inflammatory properties (Patra and Baek, 2016; Rincón-Mejía et al., 2012; Sacchetti et al., 2005). Also they have been associated with modulation of various genetic pathways (Khoury et al., 2016). In recent years there has been increasing interest in the use of biologically active organic compounds that have the ability to eliminate pathogenic bacteria; this is mainly due to the resistance that bacteria have developed to antibiotics (Marston et al., 2016). Examples of essential oils that have shown insecticidal, antioxidant, antibacterial, antifungal and antiviral properties are: Lippia berlandieri (oregano), Thymus vulgaris (thyme), Cinnamomum verum (cinnamon) and others. These essential oils contain phenolic compounds, such as carvacrol and thymol (monoterpenic substances), as main components of potent antimicrobial activity (Ali et al., 2015; Burt, 2004; Cowan, 1999; Flores-Encarnación et al., 2016). Studies reported by some authors have shown that the $S$. aureus strains have been more susceptible to a high number of essential oils: eucalyptus, lemongrass, patchouli, black pepper, clary sage, tea tree, vetiver. The antibacterial activity has been recorded at values below $0.30 \mathrm{mgmL}^{-1}$ (Teles-Andrade et al., 2014). In general, it has been reported that Grampositive bacteria are more sensitive to natural products that Gram-negative bacteria (FloresEncarnación et al., 2016; Silva and Fernandes-Junior, 2010; Trombetta et al., 2005). As it is known Gram-negative bacteria have an envelope consisting of lipopolysaccharides linked to outer membrane, which restrict diffusion of hydrophobic molecules (Nazzaro et al., 2013). Gram-negative bacteria require greater concentrations of essential oils to inhibit their growth (Trombetta et al., 2005). The mechanisms from antibacterial activity of essential oils have been determined. The essential oils are hydrophobic subtances that penetrate the bacterial membranes, leading to disruption of cell membrane integrity; it results in the destabilization of bacterial membranes, changes in bacterial membrane structure, alteration of the cell permeability, disturbance on respiration, modification of bacterial quorum sensing, potassium leakage from cells, effects on membrane potential (proton translocation), changes in $\mathrm{pH}$ gradient and ATP production of bacterial cell dissolution of the proton motive force and subsequent reduction in ATP synthesis (Flores-Encarnación et al., 2016; Flores-Encarnación et al., 2019; Nostro and Papalia, 2012; O’Bryan et al., 2015; Rajendran et al., 2014).

\section{EMERGENCE OF VIRAL INFECTIONS}

In recent years, outbreaks of different infectious diseases have been recorded worldwide (Ahmed et al., 2017). Some urban practices, such as the change in land use, the uncontrolled growth of populations, frequent contact with domesticated and wild animals, the human invasion of natural areas, the deficiency in health services (among them, the no use of vaccines) and the climate change, have been factors that promoted the emergence and re-emergence of various infectious diseases, including those of viral origin. In this case, the passage of certain viruses present in wild and domestic animals to man has been observed, causing the emergence of new diseases (Ahmed et al., 2017; Daszak et al., 2001; Ołpiński, 2012; Rahim and Uddin, 2017).Viral infections that are considered emerging today are not new. For example, the dengue fever emerged simultaneously in South-East Asia, Africa, and North America during the 18th century, whereas influenza (Spanish flu) emerged at the beginning of $20^{\text {th }}$ century, killing between 25 and 40 million people in five continents (Chastel, 
2007; Taylor et al., 2001). The severe acute respiratory syndrome virus (SARS), bird flu, swine flu, Ebola virus disease, Zika and Chikungunya fever have emerged in recent years (Ahmed et al., 2017). In all cases, the participation of animal reservoirs or vectors are considered for the transmission of the viral disease to human populations.

\section{EsSential OILS ANd Pathogenic Viruses}

Over the years, different properties that essential oils possess have been observed. One of the most important properties for humans is that them have anti-inflammatory, antioxidant and antiviral activity. Inflammation is a physiological response to a variety of agents including infectious microorganisms, toxic chemical compounds and physical injury (Pérez et al., 2011).For example, the seed essential oil of Afromomum melengueta (widespread across tropical Africa as well as on some islands of the Indian Ocean) showed great potential antioxidant and anti-inflammatory properties (Jazet et al., 2008). It has been reported that essential oil of A. melengueta is rich in sesquiterpenes and monoterpenes like limonene, 1, 8-cineole, pinenes, linalool and (E)-b-ocimene, as the major components (Pérez et al., 2011). The essential oil of Aucoumea klaineana, Canarium scheinfurthii, Calycorectes sellowianus also have shown anti-inflammatory properties and it has been reported that they contain as components; alfa-pinene, alfa-phelandrene, para-cymene, 1, 8-cineole, limonene, alfaterpineol, guaioland beta-caryophyllene (Apel et al., 2010; Jazet et al., 2008). The essential oil of Cinnamomum insularimontanum and its major constituents, such as trans-cinnamaldehyde, caryophyllene oxide, L-borneol, L-bornyl acetate, eugenol, beta-caryophyllene, E-nerolidol, and cinnamyl acetate have anti-inflammatory activity (Tung et al., 2008). Essential oils contained in Citrus sinensis L. (Rutaceae) and Citrus sunki (Hayata) Tanaka (Rutaceae) showed anti-inflammatory activity. It has been reported that they contain as major components dl-limonene and beta-myrcene (Jazet et al., 2008; Yang et al., 2010). It has been reported that in inflammation a variety of intracellular signaling pathways are activated, which comprise cell surface receptors, tyrosine kinases and transcription factors, leading to over expression of pro-inflammatory genes. Cellular components such as mast cells and leukocytes recruit to the site of damage causing a respiratory explosion. The respiratory explosion is accompanied by increased oxygen consumption: the releasing and accumulation of reactive oxygen species (ROS) and reactive nitrogen species (RNS) occurs at the site of damage (Grivennikov et al., 2010; Kodydkova et al., 2013; Martins de Lavor et al., 2018; Vendramini-Costa et al., 2012). When ROS and RNS production is greater than cellular antioxidant capacity (by superoxide dismutase, glutathione peroxidase, catalase and others), oxidative stress can damage DNA, proteins, and lipids. In addition to the above, in the inflammatory process diverse protein kinases are activated altering cell proliferation. It has been observed that in the chronic inflammatory process, the excessive activation of signaling pathways causes also the activation of certain transcription factors (such as NF-kBand activator protein-1, AP-1). The cyclooxygenase $(\mathrm{COX})$ and inducible nitric-oxide synthase (iNOS) enzymes, cytokines and chemokines have also been reported to play a role in oxidative stress-induced inflammation (Federico et al., 2007; Martins et al., 2018; Wu et al., 2014).

Another of the properties observed in essential oils is their antioxidant activity. Essential oils contain more than 200 diverse compounds mostly made of monoterpenes and sesquiterpenes and branched chemicals as aliphatic aldehydes, ketones, esters and alcohols. The presence of these substances in essential oils produces antioxidant and antimicrobial effects (Moattar et al., 2018; Pellegrini et al., 2018). It's known that ROS (the superoxide anion and hydroxyl radical) are cytotoxic and promote tissue injury, while the antioxidant substances act as the major defense mechanism protecting to cells from the damages caused by free radicals (Moattar et al., 2018).Essential oil of Calamintha officinalis (commonly called melissa) has antioxidant activity. Different authors have reported the chemical composition of essential oil of C. officinalis, which contains:1,8-cineole, pulegone, limonene, carvone, pulegone, para-menthone, beta-bisabolene, germacrene, beta-bourbonene, piperitenone, transcaryophyllene, neo-dihydrocarveol, dihydrocarveol, as the major components of their essential oil (Astani et al., 2011; Bouchra et al., 2003; Morteza-Semnani and Akbarzadeh, 2007; Nickavar and Mojab, 2005).Moattar et al., (2018) observed that essential oil of $C$. officinalis had free radical scavenging activity and that catalase and superoxide dismutase activities significantly were increased. Catalase activity is a major antioxidant defense enzyme that produce the decomposition of $\mathrm{H}_{2} \mathrm{O}_{2}$ protecting to DNA, proteins, and lipids from oxidative stress. 


\section{EfFect of EsSEntial Oils On Infection-CAusing Pathogenic Viruses}

In this section, some examples of essential oils and their antiviral activity against pathogenic viruses are are shown. Haddad et al., (2019) report edon A549 human epithelial cells infected with Zika virus that the Ayapana triplinervis essential oil inhibited infection. The effect was observed using both essential oil as thymhydroquinone dimethyl ether (main component of this essential oil) at noncytotoxic concentrations. They reported $\mathrm{IC}_{50}$ values of $38 \mu \mathrm{g} \mathrm{mL}{ }^{-1}$ by A. triplinervis essential oil and $45 \mu \mathrm{g} \mathrm{mL} \mathrm{m}^{-1}$ by thymhydroquinone dimethyl ether. This authors proposed that thymhydroquinone dimethyl ether could block the early stages of virus infection (Haddad et al., 2019).It's known that Zika virus is an emerging mosquito-borne virus of medical importance. Zika infection has been associated with serious neurological disorders, such as neonatal microcephaly, Guillain-Barré syndrome and meningoencephalitis in infected adults and birth defects in affected infants. Sexual, vertical, and blood transmissions have also been reported (Cao-Lormeau et al., 2016; Noorbakhsh et al., 2019; Parra et al., 2016). Other emerging infections in the world is dengue transmitted by vectors. There is no antiviral drugs for treatment for any of the Flavivirus and an effective vaccine for human use is not yet available to prevent dengue (Ocazionez et al., 2010).

Dengue fever is the most prevalent human arboviral disease in tropical and subtropical regions worldwide. Dengue virus is a global health threat that is primarily acquired through the bites of infected mosquitoes and responsible for over 100 million infections and 20,000 deaths annually (Douglas et al., 2020; Murray et al., 2013). It has been reported in vitro that the Lippia alba and Lippia citriodora essential oils inhibited the replication of dengue virus serotypes. The use of the Lippia sp. essential oils could be a potential resource for treatment of tropical disease like dengue, especially in developing countries (Ocazionez et al., 2010). The L. citriodora infusions have been used for the treatment of colds, flu, bronchitis, coughs, asthma and others (Ocazionez et al., 2010; Pascual et al., 2001). It has been reported that $L$ alba essential oil contains as major components: carvone (40-51\%), limonene (30-33\%) and bicyclesesquiphellandrene (7-9\%). The $\mathrm{IC}_{50}$ of $L$. alba essential oil for dengue virus serotypes (DENV-1, DENV-2, DENV-3 and DENV-4) were also determinated. The values reported by authors were: $10.1,0.4,32.6$ and $21.1 \mu \mathrm{g} \mathrm{mL}^{-1}$, respectively (da Silva et al., 2020; Ocazionez et al., 2010). Viral inhibitory effect was not observed by addition of the essential oil after virus adsorption. It seems that inhibitory effect of Lippia sp. essential oil is attributed to direct inactivation of virus before adsorption on the host cell (da Silva et al., 2020).

Several authors have reported the effect of essential oils on the yellow fever virus. Yellow fever virus belongs to the family Flaviviridae. This virus has been responsible for devastating epidemics and for hepatic and hemorrhagic diseases (Gómez et al., 2013).Yellow fever is a viral hemorrhagic fever endemic in South America and sub-Saharan Africa. It is transmitted to humans through the bite of the Aedes or Haemagogus mosquitoes (Meneses et al., 2009; Monath and Barrett, 2003).It has been reported in vitro that the L. alba and L. citriodora essential oils have showed antiviral activity; the major components of this essential oils were reported with: carvone (40-51\%), limonene (30-33\%) and bicyclosesquiphellandrene (7-9\%) in L. alba and geranial (19\%), neral (15.6\%), limonene (11\%) and 1,8-cineole (5\%) on L. citriodora (da Silva et al., 2020; Ocazionez et al., 2010). To investigate the antiviral mode of action, essential oils were added before and after adsorption of virus to Vero and HeLa. In both cases it was observed the antiviral activity (Gómez et al., 2013).It is speculated that direct inactivation of virus by the essential oils can be due to disruption of lipid viral envelope because the major components in the essential oils are terpenes and terpenoids (Meneses et al., 2009). Other authors have reported that these compounds have showed anti-HIV activity inhibiting the virus adsorption to target cell and causing inactivation of virus reverse transcriptase (Meneses et al., 2009; Sun et al., 1996). In case of yellow fever virus, the antiviral effect of $L$. alba and L. Citriodora essential oils could be explained by the presence of lipid compounds as carvone, limonene, geranial, neral, and others. Another of the medically important viral infection-causing agents is the herpes simplex virus. Herpes simplex virus (HSV) belongs to the alpha subfamily of the human herpesvirus family and includes HSV1 and HSV2, which are responsible for pandemics of various herpes diseases (Lan and Luo, 2017; Xu et al., 2019). HSV1 is transmitted through contact with saliva and causes recurrent cold sores, while HSV2 is transmitted primarily through sexual contact and is associated with urogenital and neonatal infections (Schuhmacher et al., 2003). In this context, essential oils are promising candidates for the topical treatment of recurrent herpes infections. It has been that, the essential oils of Melaleuca alternifolia, Mentha piperita, Thymus vulgaris and T. capitatus have 
shown antiviral properties against enveloped viruses. The major components of this essential oils were reported with: terpinen-4-ol (30-48\%), $\gamma$-terpinene (10-28\%), $\alpha$-terpinene (5-13\%), 1,8-cineole (up to $15 \%$ ), terpinolene (1.5-5\%), p-cymene (0.5-12\%), $\alpha$-pinene (1-6\%), $\alpha$-terpineol (1.5-8\%) on $M$. alternifolia; menthol (43.8\%), menthone (19.7\%), menthyl acetate (6.5\%), 1,8-cineole (5.0\%) on $M$. piperita; thymol (43.9\%), carvacrol (14.4\%), p-cymene (10.5\%), $\beta$-caryophyllene (7.0\%), $\gamma$-terpinene (5.1\%); carvacrol (68.6\%), p-cymene (4.8\%), $\gamma$-terpinene (3.0\%), and $\beta$-caryophyllene $(2.9 \%)$ on $T$. capitatus (da Silva et al., 2020; El Moussaoui et al., 2013; Koch et al., 2008; Minami et al., 2003; Setzer, 2016).It has been reported that these compounds exhibit direct virucidal activity to inhibit intracellular replication, o well interacting with HSV particles, thus inhibiting cell binding and adsorption (Schnitzler, 2019). The mechanism of action of the compounds consists mainly in the direct inactivation of the extracellular HSV2 particles together with a lesser spread of the virus from cell to cell, limiting the production of viral progeny (Toujani et al. 2018).

Other essential oils reported with antiviral activity against HVS1 and HSV2 are: Artemisia douglasiana, A. arborescens and Eugenia caryophyllus essential oils (Schnitzler, 2019). The 2019 novel coronavirus (2019-nCoV) or the severe acute respiratory syndrome corona virus 2 (SARS-CoV2) is rapidly spreading from its origin in Wuhan City of Hubei Province of China to the rest of the world. It is a positive single-stranded RNA virus from the enveloped coronavirus family. Symptoms of SARS-CoV-2 infection are cough, fever, digestive disturbances, respiratory problems, which cause more than $15 \%$ of mortality worldwide (Singhal et al., 2020; Wang et al., 2020). Angiotensin converting enzyme receptor 2 (ACE2), a host cell receptor, has been found to play a crucial role in viral cell entry; therefore, ACE2 blockers may be a potential target for antiviral intervention. It has been reported that geranium and lemon essential oils have powerful ACE2 inhibitory effects, so the components of them are valuable natural antiviral agents that could contribute to prevention of invasion by SARS-CoV-2 in the human epithelial cells (Kumar et al., 2020). Recent in silico studies reported that organosulfur compounds in garlic essential oil and other natural products, such as baicalin, scutellarin, hesperetin, nicotianamine, glycyrrhizin, (E,E)- $\alpha$-farnesene, (E)- $\beta$-farnesene, and (E, E)-farnesol, have the potential to bind the human ACE2 receptor, thereby possibly blocking SARS-CoV-2 cell entry (da Silva et al., 2020; Kumar et al., 2020; Thuy et al., 2020).At present, there is no definite treatment or vaccine developed for the coronavirus that causes SARS-CoV-2. More studies have to be done in this regard.

\section{CONCLUSION}

The essential oils have shown antioxidant, antibacterial, antifungal and antiviral properties. In the search for new drugs to combat antibiotic-resistant bacterial infections, some essential oils and their components seem to be a potential alternative. The same occurs in viral infections, especially in some emerging infections for which there is neither optimal treatment nor vaccines. At present, essential oils are very likely not going to solve the problem of emerging viral infections, however these substances or their components could be used as prophylactic measures. It is important that more studies are done on the benefits that essential oils can offer for human health.

\section{ACKNOWLEDGEMENTS}

Thank to PRODEP and Facultad de Medicina-BUAP for the facilities provided for the development of this work.

\section{REFERENCES}

[1] Abbassi F. and Hani K. (2012). In vitro antibacterial and antifungal activities of Rhus tripartitum used as antidiarrhoeal in Tunisian folk medicine. Nat. Prod. Res. 26:2215-2218.

[2] Abu-Shanab B., Adwan D., Abu-Safiya D., Jarrar N. and Adwan K. (2005). Antibacterial activities of some plant extracts utilized in popular medicine in Palestine. Turk J. Biol. 28:99-102.

[3] Adeyemi M.M.H. (2010). The potential of secondary metabolites in plant material as deterents against insect pests: A review. Afr. J. Pure and Appl. Chem. 4:243-246.

[4] Ali B., Al-Wabel N.A. Shams S., Ahamad A., Khan S.A. and Anwar F. (2015). Essential oils used in aromatherapy: a systemic review. Asian Pac. J. Trop. Biomed. 5:601-611.

[5] Al-Shuneigat J., Al-Sarayreh S., Al-Saraireh Y., Al-Qudah M. and Al-Tarawneh I. (2014). Effects of wild Thymus vulgaris essential oil on clinical isolates biofilm-forming bacteria. J. Dental Med. Sci. 13:62-66.

[6] Ahmed J.U., Rahim M.A. and Uddin K.N. (2017). Emerging viral diseases. Birdem Med. J. 7:224-232. 
[7] Apel M., Lima M.E.L., Sobral M., Young M.C.C., Cordeiro I., Schapoval E.E.S., Henriques A.T. and Moreno P.R.H. (2010). Anti-inflammatory activity of essential oil from leaves of Myciaria tenella and Calycorectes sellowianus. Pharm. Biol. 48:433-438.

[8] Astani A., Reichling J. and Schnitzler P. (2011). Screening for antiviral activities of isolated compounds from essential oils. Evid. Based Complement. Alternat. Med. 2011:1-8.

[9] Bereksi M.S., Hassaïne H., Bekhechi C. and Abdelouahid D.E. (2018). Evaluation of antibacterial activity of some medicinal plants extracts commonly used in Algerian traditional medicine against some pathogenic bacteria. Pharmacogn J. 10:507-512.

[10] Bouchra C., Achouri M., Idrissi Hassani L.M. and Hmamouchi M. (2003). Chemical composition and antifungal activity of essential oils of seven Moroccan labiatae against Botrytis cinerea Pers: Fr. J. Ethnopharmacol. 89:165-169.

[11] Burt, S. (2004). Essential oils: their antibacterial properties and potential applications in foods-a review. Inter. J. Food Microbiol. 94:223-253.

[12] Cao-Lormeau, V.M., Blake A., Mons S., Lastère S., Roche C., Vanhomwegen J., Dub T., Baudouin L., Teissier A., Larre P., Vial A.L., Decam C., Choumet V., Halstead S.K., Willison H.J., Musset L., Manuguerra J.C., Despres P., Fournier E., Mallet H.P., Musso D., Fontanet A., Neil J. and Ghawché F. (2016). Guillain-Barré syndrome outbreak associated with Zika virus infection in French Polynesia: A case-control study. Lancet. 387:1531-1539.

[13] Chastel C. (2007). Global threats from emerging viral diseases. Bull Acad. Natl. Med. 191:1563-1577.

[14] Cowan M.M. (1999). Plant products as antimicrobial agents. Clin. Microbiol. Rev. 12:564-582.

[15] da Silva J.K.R., Figueiredo P.L.B., Byler K.G. and Setzer W.N. (2020). Essential oils as antiviral agents, potential of essential oils to treat SARS-CoV-2 infection: an in-silico investigation. Int. J. Mol. Sci. 21:3426-3461.

[16] Daszak P., Cunningham A.A. and Hyatt A.D. (2001). Anthropogenic environmental change and the emergence of infectious diseases in wildlife. Acta Tropica. 78:103-116.

[17] Diao, W.R., Hu, Q.P., Feng, S.S., Li, W.Q. and Xu, J.G (2013). Chemical composition and antibacterial activity of the essential oil from green huajiao (Zanthoxylum schinifolium) against selected foodborne pathogens. J. Agric. Food Chem. 3:6044-6049.

[18] Douglas K.O., Dutta S.K., Martina B., Anfasa F., Samuels T.A. and Hilaire M.G.S. (2020). Dengue fever and severe dengue in Barbados, 2008-2016. Trop. Med. Infect. Dis. 5:68-88.

[19] El Moussaoui N., Sanchez G., Khay E.O., Idaomar M., Ibn Mansour A., Abrini J. and Aznar R. (2013). Antibacterial and antiviral activities of essential oils of northern Moroccan plants. Br. Biotechnol. J. 3:318331.

[20] Federico A., Morgillo F., Tuccillo C., Ciardiello F. and Loguercio C. (2007). Chronic inflammation and oxidative stress in human carcinogenesis. Intern. J. Cancer. 121:2381-2386.

[21] Feldmann H., Czub M., Jones S., Dick D., Garbutt M., Grolla A. and Artsob H. (2002). Emerging and reemerging infectious diseases. Med. Microbiol. Immunol. 191:63-74.

[22] Flores-Encarnación M., Morales-Báez J.R., Gutiérrez-Aguilar G.R., Cabrera-Maldonado C. and Silvia del Carmen García-García. (2019). The effect of Thymus vulgaris essential oil on the viability of eukariotic cells. Int. J. Curr. Res. 11:8001-8006.

[23] Flores-Encarnación M., Nava-Nolazco R.M., Aguilar-Gutiérrez G.R., Carreño-López R. and GarcíaGarcía S.C. (2018). The effect of Thymus vulgaris on growth and biofilm formation of uropathogenic Escherichia coli. Afr. J. Microbiol. Res. 12:237-242.

[24] Flores-Encarnación M., Nava-Nolazco R.M., Carreño-López R., Aguilar-Gutiérrez G.R., García-García S.C. and Cabrera-Maldonado C. (2016). The antibacterial effect of plant-based essential oils. Intern. J. Res. Studies Biosc. 4:1-6.

[25] Gómez L.A., Stashenko E. and Ocazionez R.E. (2013). Comparative study on in vitro activities of citral, limonene and essential oils from Lippia citriodora and L. albaon yellow fever virus. Nat. Prod. Comm. $8: 249-252$.

[26] Grivennikov S.I., Greten F.R. and Karin M. (2010). Immunity, inflammation and cancer. Cell. 140: 883899.

[27] Haddad J.G., Picard M., Bénard S., Desvignes C., Desprès P., Diotel N. and El Kalamouni C. (2019). Ayapana triplinervis essential oil and its main component thymohydroquinone dimethyl ether inhibit Zika virus at doses devoid of toxicity in Zebrafish. Mol. 24:3447-3459.

[28] Hamid A.A., Aiyelaagbe O.O. and Usman L.A. (2011). Essential oils: its medicinal and pharmacological uses. Intern. J. Curr. Res. 3:86-98. 
[29] Hussein N.H., Rasool K.H. and Hussein J.D. (2014). Effects of Coriandrum sativum, Thymus vulgaris, Borago officinalis and Pimpinella anisum on biofilm Escherichia coli. J. Gen. Environ. Res. Conserv. 2:219-230.

[30] Jazet D.P.M., Fekam P.M.B., Sameza M.L., Ndongson D.B., Kwazou N.L. (2008). Investigations of the essential oils of some Afromomum species (Zingiberaceae) from Cameroon as potential antioxidant and anti-inflammatory agents. Int. J. Esset. Oil Ther. 2:149-155.

[31] Khoury R.E., Atoui A., Verheecke C., Maroun R., Khoury A.E., and Mathieu F. (2016). Essential oils modulate gene expression and ochratoxin A production in Aspergillus carbonarius. Toxins. 8:1-14.

[32] Koch C., Reichling J., Schneele J. and Schnitzler P. (2008). Inhibitory effect of essential oils against herpes simplex virus type 2. Phytomed. 15:71-78.

[33] Kodydkova J., Vavrova L., Stankova B., Macasek J., Krechler T. and Zak A. (2013). Antioxidant status and oxidative stress markers in pancreatic cancer and chronic pancreatitis. Pancreas. 42:614-621.

[34] Kumar K.J. S., Vani M.G., Wang C.S., Chen C.C., Chen Y.C., Lu L.P., Huang C.H., Lai C.S. and Wang S.Y. (2020). Geranium and lemon essential oils and their active compounds downregulate angiotensinconverting enzyme 2 (ACE2), a SARS-CoV-2 spike receptor-binding domain, in epithelial cells. Plants. 9:770-782.

[35] Lan K. and Luo M.H. (2017). Herpesviruses: epidemiology, pathogenesis, and interventions. Virol. Sin. 32:347-348.

[36] Marston H.D., Dixon D.M., Knisely J.M., Palmore T.N. and Fauci A.S. (2016). Antimicrobial resistance. JAMA. 316:1193-1204.

[37] Martins de Lavor E., Cavalcante Fernandes A.W., Braga de Andrade Teles R., Barbosa Pereira Leal A.E., Gonçalves de Oliveira Júnior R., Gama e Silva M., de Oliveira A.P., Cabral Silva J, Tais de Moura Fontes Araújo M., Melo Coutinho H.D., Alencar de Menezes I.R., Picot L. and Guedes da Silva Almeida J.R. (2018). Essential oils and their major compounds in the treatment of chronic inflammation: a review of antioxidant potential in preclinical studies and molecular mechanisms. Hindawi Oxid. Med. Cell. Longevity. 2018:1-23.

[38] Meneses R., Ocazionez R.E., Martínez J.R. and Stashenko E.E. (2009). Inhibitory effect of essential oils obtained from plants grown in Colombia on yellow fever virus replication in vitro. Ann. Clin. Microbiol. Antimicrob. 8:8-14.

[39] Minami M., Kita M., Nakaya T., Yamamoto T., Kuriyama H. and Imanishi J. (2003). The inhibitory effect of essential oils on herpes simplex virus type-1 replication in vitro. Microbiol. Immunol. 47:681-684.

[40] Moattar M.F.S., Sariri R., Giahi M. and Yaghmaee P. (2018). Essential oil composition and antioxidant activity of Calamintha officinalis. J. Appl. Biotechnol. Rep. 5:55-58.

[41] Monath T.P. and Barrett A.D. (2003). Pathogenesis and pathophysiology of yellow fever. Adv. Virus Res. 60:343-395.

[42] Morteza-Semnani K. and Akbarzadeh M. (2007). The essential oil composition of Calamintha officinalis Moench from Iran. J. Essential Oil Bearing Plants. 10:494-498.

[43] Murray N.E.A., Quam M.B. and Wilder-Smith A. (2013). Epidemiology of dengue: past, present and future prospects. Clin. Epidemiol. 5:299-309.

[44] Nazzaro F., Fratianni F., De Martino L., Coppola R. and De Feo V. (2013). Effect of essential oils on pathogenic bacteria. Pharmaceut. 6:1451-1474.

[45] Nickavar B. and Mojab F. (2005). Hydrodistilled volatile constituents of Calamintha officinalis Moench from Iran. J. Essential Oil Bearing Plants. 8:23-27.

[46] Nostro A. and Papalia T. (2012). Antimicrobial activity of carvacrol: current progress and future prospectives. Recent Pat. Antiinfect. Drug Discov. 7:28-35.

[47] Noorbakhsh F., Abdolmohammadi K., Fatahi Y., Dalili H., Rasoolinejad M., Rezaei F., Salehi-Vaziri M., Shafiei-Jandaghi N.Z., Gooshki E.S., Zaim M. and Nicknam. M.H. (2019). Zika virus infection, basic and clinical aspects: a review article. Iran J. Public Health. 48:20-31.

[48] O’Bryan C.A., Pendleton S.J., Crandall P.G. and Ricke S.C. (2015). Potential of plant essential oils and their components in animal agriculture- in vitro studies on antibacterial mode of action. Frontiers Vet. Sci. 2:1-8.

[49] Ocazionez R.E., Meneses R., Torres F.Á. and Stashenko E. (2010). Virucidal activity of colombian Lippia essential oils on dengue virus replication in vitro. Mem. Inst. Oswaldo Cruz, Rio de Janeiro. 105:304-309.

[50] Ołpiński M. (2012). Anti-vaccination movement and parenteral refusals of immunization of children in USA. Pediatria Polska. 87:381-385. 
[51] Pascual M., Slowing K., Carretero E., Sánchez-Mata D. and Villar A. (2001). Lippia: traditional uses, chemistry and pharmacology: a review. J. Ethnopharmacol. 76:201-214.

[52] Parra B., Lizarazo J., Jiménez-Arango J.A., Zea-Vera A.F., González-Manrique G., Vargas J., Angarita J.A., Zuñiga G., Lopez-Gonzalez R., Beltran C.L., Rizcala K.H., Morales M.T., Pacheco O., Ospina M.L., Kumar A., Cornblath D.R., Muñoz L.S., Osorio L., Barreras P. Pardo C.A. (2016). Guillain-Barré syndrome associated with Zika virus infection in Colombia. New Engl. J. Med. 375:1513-1523.

[53] Patra J.K. and Baek K.H. (2016). Antibacterial activity and action mechanism of the essential oil from Enteromorpha linza L. against foodborne pathogenic bacteria. Molecules. 21:1-11.

[54] Pellegrini M., Ricci A., Serio A., Chaves-López C., Mazzarrino G., D’Amato S., Lo Sterzo C. and Paparella A. (2018). Characterization of essential oils obtained from Abruzzo autochthonous plants: antioxidant and antimicrobial activities assessment for food application. Foods. 7:19-33.

[55] Pérez S., Zavala M., Arias L. and Ramos M. (2011). Anti-inflammatory activity of some sssential oils. J. Essential Oil Res. 23:38-44.

[56] Rahim M.A. and Uddin K.N. (2017). Chikungunya: an emerging viral infection with varied clinical presentations in Bangladesh: reports of seven cases. BMC Res. Notes. 10:410-414.

[57] Rajendran M.P., Pallaiyan B.B., Selvaraj N., (2014). Chemical composition, antibacterial and antioxidant profile of essential oil from Murraya koenigii (L.) leaves. AJP. 4:200-214.

[58] Rincón-Mejía,C.A., Castaño-Osorio,J. Carlos, and Ríos-Vázquez, E. (2012). Actividad biológica de los aceites esenciales de Acmella ciliata (Kunth) Cass. Rev. Cub. Plantas Med. 17:160-171.

[59] Sacchetti, G., Maietti, S., Muzzoli, M., Scaglianti, M., Manfredini, S., Radice, M. and Bruni, R. (2005). Comparative evaluation of 11 essential oils of different origin as functional antioxidants, antiradicals and antimicrobials in foods. Food Chem. 91:621-632.

[60] Sambyal S.S., Sharma P. and Shrivastava D. (2017). Anti-biofilm activity of selected plant essential oils against Pseudomonas aeruginosa and Staphylococcus aureus. Int. J. Curr. Microbiol. App. Sci. 6:444-450.

[61] Schnitzler P. (2019). Essential oils for the treatment of herpes simplex virus infections. Chemother. 64:1-7.

[62] Schuhmacher A., Reichling J. and Schnitzler P. (2003). Virucidal effect of peppermint oil on the enveloped viruses herpes simplex virus type 1 and type 2 in vitro. Phytomed. 10:504-510.

[63] Setzer W.N. (2016). Essential oils as complementary and alternative medicines for the treatment of influenza. Am. J. Essent. Oil Nat. Prod. 4:16-22.

[64] Shuaib A. Rohit A. and Piyush M. (2016). A review article on essential oils. J. Med. Plants Stud. 4:237240.

[65] Silva N.C.C. and Fernandes-Junior A. (2010), Biological properties of medicinal plants: a review of their antimicrobial activity. J. Venom. Anim. Toxins Incl. Trop. Dis. 3:402-413.

[66] Singhal T. (2020). A review of coronavirus disease-2019 (COVID-19). Indian J. Pediatrics. 87:1022310228.

[67] Sun H., Qiu S., Lin L., Wang Z., Lin Z., Pengsuparp T., Pezzuto J., Fong H., Cordell G., Farnsworth N. (1996). Nigranoic acid, a triterpenoid from Schisandra sphaerandra that inhibits HIV-1 reverse transcriptase. J. Nat. Prod. 59:525-527.

[68] Taylor L.H., Latham S.M. and Woolhouse M.E. (2001). Risk factors for human disease emergence. Phil. Trans. R. Soc. Lond. B Biol. Sci. 356:983-989.

[69] Teles-Andrade B.F.M., Nunes-Barbosa L., da Silva-Probst I. and Fernandes-Júnior A. (2014). Antimicrobial activity of essential oils. J. Essential Oil Res. 26:34-40.

[70] Toujani M.M., Rittà M., Civra A., Genovese S., Epifano F., Ghram A. and Donalisio M. (2018). Inhibition of HSV-2 infection by pure compounds from Thymus capitatus extract in vitro. Phytother. Res. 32:15551563.

[71] Trombetta D., Castelli F., Sarpietro M.G., Venuti V., Cristani M., Daniele C., Saija A., Mazzanti G.and Bisignano G. (2005). Mechanisms of antibacterial action of three monoterpenes. Antimicrob. Agents Chemother. 49:2474-2478.

[72] Tung Y.T., Chua M.T., Wang S.Y. and Chang S.T. (2008). Anti-inflammation activities of essential oil and its constituents from indigenous cinnamon (Cinnamomum osmophloeum) twigs. Bioresource Technol. 99:3908-3913.

[73] Thuy B.T.P., My T.T.A., Hai N.T.T., Hieu L.T., Hoa T.T., Thi Phuong Loan H.T., Triet N.T., Anh T.T.V., Quy P.T., Tat P.V., Hue N.V., Quang D.T., Trung N.T., Tung V.T., Huynh L.K. and Nhung N.T.A. (2020). Investigation into SARS-CoV-2 resistance of compounds in garlic essential oil. ACS Omega. 5:8312-8320. 
[74] Upadhyay A., Upadhyaya I., Kollanoor-Johny A. and Venkitanarayanan K. (2013). Antibiofilm effect of plant derived antimicrobials on Listeria monocytogenes. Food Microbiol. 36:79-89.

[75] Vendramini-Costa D.B. and Carvalho J.E. (2012). Molecular link mechanisms between inflammation and cancer. Curr. Pharm. Design. 18:3831-3852.

[76] Wang C., Horby P.W., Hayden F.G. and Gao G.F. (2020). A novel coronavirus outbreak of global health concern. Lancet. 395:470-473.

[77] Wu Y., Antony S., Meitzler J.L. and Doroshow J.H. (2014). Molecular mechanisms underlying chronic inflammation-associated cancers. Cancer Lett. 345:164-173.

[78] Xu X., Zhang Y. and Li Q. (2019). Characteristics of herpes simplex virus infection and pathogenesis suggest a strategy for vaccine development. Rev. Med. Virol. 29:2054-2066.

[79] Yang E.J., Kim S.S, Moon J.Y., Oh T.H., Baik J.S. Lee N.H. and Hyun C.G. (2010). Inhibitory effects of Fortunella japonica var. margarita and Citrus sunki essential oils on nitric oxide production and skin pathogens. Acta Microbiol. Inmunol. Hung. 57:15-27.

Citation: Flores-Encarnación, M. et al., "The Essential Oils and the Effect on Infection-Causing Pathogenic Viruses”, International Journal of Research Studies in Biosciences, 8(7), pp. 7-15. DOI:https://doi.org/10.20431/2349-0365.0807002

Copyright: (C) 2020 Authors, This is an open-access article distributed under the terms of the Creative Commons Attribution License, which permits unrestricted use, distribution, and reproduction in any medium, provided the original author and source are credited. 